Xavier University

\title{
Exhibit
}

\section{Shades of Shakespeare in the Queering of Hill House}

Graley Herren

Xavier University

Follow this and additional works at: https://www.exhibit.xavier.edu/english_faculty

Part of the English Language and Literature Commons

\section{Recommended Citation}

Herren, Graley, "Shades of Shakespeare in the Queering of Hill House" (2020). Faculty Scholarship. 592. https://www.exhibit.xavier.edu/english_faculty/592

This Article is brought to you for free and open access by the English at Exhibit. It has been accepted for inclusion in Faculty Scholarship by an authorized administrator of Exhibit. For more information, please contact exhibit@xavier.edu. 


\section{Critique: Studies in Contemporary Fiction}

\section{Shades of Shakespeare in the Queering of Hill House}

\section{Graley Herren}

To cite this article: Graley Herren (2020): Shades of Shakespeare in the Queering of Hill House, Critique: Studies in Contemporary Fiction, DOI: 10.1080/00111619.2020.1789542

To link to this article: https://doi.org/10.1080/00111619.2020.1789542

曲 Published online: 02 Jul 2020.

Submit your article to this journal ๘

Q View related articles $\sqsubset$

View Crossmark data 


\title{
Shades of Shakespeare in the Queering of Hill House
}

\author{
Graley Herren \\ English, Xavier University, Cincinnati, Ohio, USA
}

\begin{abstract}
In her classic horror novel The Haunting of Hill House, Shirley Jackson appropriates Shakespearean romantic comedies and tragedies for the purposes of lesbian gothic. Shakespeare's plays provide signposts for leading (as well as misleading) protagonist Eleanor Vance through the fraught terrain of restrictive gender expectations, patriarchal persecution, and queer desire in Fifties America. The present article develops a queer reading of Eleanor's relationship with Theodora. This essay pays particular attention to the ways Jackson uses Shakespeare to structure and complicate the erotic subtext of The Haunting of Hill House.
\end{abstract}

In Danse Macabre Stephen King praises Shirley Jackson's 1959 horror classic The Haunting of Hill House as "one of the finest books to ever come out of the genre" (175). It would be more accurate to reverse those terms and say that the genre came out of the book, since Jackson is largely responsible for establishing several tropes that have since become familiar horror conventions. The Haunting of Hill House gathers a group of sarcastic paranormal investigators who crack jokes and offer metacommentaries on their predicament while staving off malevolent supernatural forces. The novel is by turns diabolical and devil-may-care, sometimes both at the same time. Jackson spawned dark progeny like The Haunting, The Shining, Poltergeist, and the Netflix series The Haunting of Hill House; but she also created lighter offspring like Scooby-Doo, The Goonies, Ghostbusters, Buffy the Vampire Slayer, Supernatural, and Stranger Things.

Influential as the novel has been, The Haunting of Hill House is itself deeply influenced by various source texts. Jackson owes debts to Gothic literature including Ann Radcliffe's The Mysteries of Udolpho, Edgar Allan Poe's The Fall of the House of Usher, and Henry James's The Turn of the Screw. She also stretches outside the genres of horror and psychological thriller, drawing heavily upon fairy tales, folk music, the L. Frank Baum Oz books, and Lewis Carroll's Alice stories. Jackson ingenuously grafts together the worlds of horror and fantasy through the naïve, romantic, repressed, and increasingly desperate perspective of her protagonist Eleanor Vance. Eleanor arrives at Hill House in search of adventure and love, but she gradually becomes overwhelmed by the strange manifestations her desires take. She is torn between her growing sexual attraction to Theodora and the rival spectral attentions of the spirits haunting Hill House. She is a displaced figure who finds herself trapped in a setting (Hill House), a narrative (The Haunting of Hill House), and an identity where she does not feel at home. Put another way, Eleanor is a rom-com protagonist miscast in a tragedy.

Jackson's primary exemplar for both romantic comedy and tragedy is William Shakespeare. As Marjorie Garber asserts in the introduction to Shakespeare After All, "Every age creates its own Shakespeare. What is often described as the timelessness of Shakespeare, the transcendent qualities for which his plays have been praised around the world and across the centuries, is perhaps better understood as an uncanny timeliness, a capacity to speak directly to circumstances the playwright could not have anticipated or foreseen" (3). The Haunting of Hill House provides a perfect case study in 
recreating Shakespeare to meet the needs of an era and culture he could scarcely have anticipated. Shakespeare's plays provide signposts for leading (as well as misleading) Eleanor through the fraught terrain of restrictive gender expectations, patriarchal persecution, and queer desire in Fifties America. The present article develops a queer reading of Eleanor's relationship with Theodora, focusing special attention on the ways in which Jackson appropriates Shakespeare to structure and to complicate the "lesbian gothic" subtext of The Haunting of Hill House. ${ }^{1}$ Think of it as an intertextual ghost-hunting expedition in search of shades of Shakespeare in the queering of Hill House.

The novel chronicles several paranormal experiments conducted by Dr. Montague at the notoriously haunted Hill House. In an effort to verify the presence of spirits, he invites Eleanor and Theodora to stay in the house and record their experiences. Eleanor and Theodora do not know each other in advance. Dr. Montague recruits them separately because of their prior paranormal credentials. As a child, Eleanor demonstrated telekinetic powers by causing a shower of stones to pelt her house for three days following the death of her father. For her part, Theodora has demonstrated an uncanny ability for guessing cards, suggesting powers of clairvoyance. Dr. Montague invites several other participants to Hill House as well, but only Eleanor and Theodora accept. The death of Eleanor's mother after a long convalescence means that the she is finally free to go away on a sabbatical. Meanwhile, Theodora has a quarrel with her roommate (and presumed lesbian partner) and is eager for a break away from home. These circumstances lead Eleanor and Theodora to join Dr. Montague and Luke Sanderson (a representative from the family that owns the mansion) for a fateful summer rendezvous at Hill House.

The novel's first overt reference to Shakespeare comes in the second chapter when Eleanor initially approaches the threshold of Hill House. All of her instincts tell her to flee, but she tries to calm her worries and counteract the house's sinister aura:

\begin{abstract}
It was an act of moral strength to lift her foot and set it on the bottom step, and she thought that her deep unwillingness to touch Hill House for the first time came directly from the vivid feeling that it was waiting for her, evil, but patient. Journeys end in lovers meeting, she thought, remembering her song at last, and laughed, standing on the steps of Hill House, journeys end in lovers meeting, and she put her feet down firmly and went up to the veranda and the door. (25; emphasis added)
\end{abstract}

Eleanor senses her vulnerability by entering this haunted house and narrative. However, either as a futile gesture of self-delusion or as a defiant gesture of self-revision, she attempts to flip the script by invoking Shakespeare's romantic comedy Twelfth Night. Eleanor's mantra “journeys end in lovers meeting" comes from the clown Feste's love song:

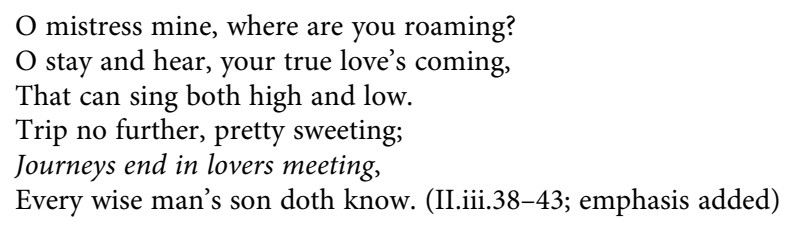

Feste's song is a classic expression of carpe diem, a call to seize the day by gathering the rosebuds of love during the short season in which they bloom. Eleanor clutches at Feste's love song like a protective talisman throughout the novel: the line "journeys end in lovers meeting" appears thirteen times in The Haunting of Hill House [25 (twice), 28, 30, 40, 66, 100, 113, 122, 156, 158, 164, 181].

Readers attuned to the insistent drumbeat of "journeys end in lovers meeting" might deduce that Twelfth Night is Jackson's primary Shakespearean touchstone. Indeed, Twelfth Night's depiction of romantic hijinks and gender subversion in an alien world harmonizes well with the erotic subtext of The Haunting of Hill House. However, Jackson invokes several other Shakespearean sources as well, and the most important of these turns out to be; A Midsummer Night's Dream. The novel's famous opening paragraph establishes the centrality of dreams:

No live organism can continue for long to exist sanely under conditions of absolute reality; even larks and katydids are supposed, by some, to dream. Hill House, not sane, stood by itself against its hills, holding darkness 
within; it had stood so for eighty years and might stand for eighty more. Within, walls continued upright, bricks met neatly, floors were firm, and doors were sensibly shut; silence lay steadily against the wood and stone of Hill House, and whatever walked there, walked alone. (1)

This opening suggests that to enter Hill House - or to enter The Haunting of Hill House - is simultaneously to enter a world of dreams and of madness. When this same opening passage repeats in the novel's conclusion, it closes the loop on an unbreakable circle from which there is no escape: an insane nightmare from which the dreamer never awakes. We do not know the full contents of the letter that convinced Eleanor to enter this haunted house, but we do know when the descent into dreams and madness began. "I am very happy that you will be joining us in Hill House," writes Dr. Montague, "'and will take great pleasure in making your acquaintance on Thursday the twenty-first of June"” (11). In other words, Eleanor arrives at Hill House on the summer solstice, Midsummer's Eve, the legendary occasion for rites of "midsummer madness," and the same temporal setting as A Midsummer Night's Dream. $^{2}$

In many respects, A Midsummer Night's Dream serves as the prototype for the social conservatism that predominates in classic romantic comedies. Shakespeare sends the young lovers Helena, Hermia, Demetrius, and Lysander to cavort in the woods on Midsummer's Eve. There they temporarily experiment with alternate pairings and come close to sexual consummation. However, the young lovers ultimately return to the daylight world of the Athenian court and assume their designated heteronormative roles as stable married couples. The status quo is briefly disrupted for erotic and comic effect, only to be reinforced in the end with the obligatory comic resolution of straight marriage and proscribed procreation to follow. However, as Melissa E. Sanchez points out in Shakespeare and Queer Theory, "For sheer range of sexual possibilities, there are few plays to match A Midsummer Night's Dream, which evokes fantasies of incest, BDSM and cross-species eroticism, both homo- and heterosexual" (112). Although these subversive impulses are ostensibly corrected by the play's conclusion, it is not so easy to bottle up polymorphous sexuality after the cork has been popped. As Sanchez concludes, "Read amidst the 'fond pageants' of promiscuous homo- and heteroerotic attachment, incest, cross-species contact and anal eroticism, the marriages anticipated at the end of A Midsummer Night's Dream are not desire's final resting place, but one among many fantasies that give desire an object and shape" (115).

Writing decades before the queer turn in literary theory and Shakespeare criticism, Shirley Jackson recognizes the capacity of A Midsummer Night's Dream for challenging traditional gender expectations and compulsive heterosexuality. She uses this romantic comedy to "give desire an object and shape" in The Haunting of Hill House. Like Shakespeare's young lovers, Jackson's four main characters are two women and two men isolated from society in a dark dreamscape where the borders blur between waking and sleep, reality and fantasy, sanity and madness. Jackson winks at her Shakespearean influence through her characters' names. The name Eleanor (sometimes abbreviated in the novel as Nell or Nellie) shares the same etymological roots as the name Helena. Late in the novel during a session of planchette (a spiritual medium's device akin to the Ouija board), Mrs. Montague perceives a paranormal presence going by the names "Helen, or Helene, or Elena" (139) and ultimately identified as "Nell" (141), making the Eleanor/Helena association even more explicit. The name Dr. Montague bears a family resemblance to Demetrius, not to mention the direct patronymic descent from the house of Montague in Romeo and Juliet (written around the same time as A Midsummer Night's Dream). The name Luke Sanderson is also remarkably similar to Lysander. These direct echoes and equations do not apply so obviously to the name Theodora. Jackson most likely chose Theodora as an inverse homage to Dorothy, acknowledging the novel's strong debt to that other fantastic foursome in The Wizard of $\mathrm{O} z$. However, as a thought experiment, take two of the play's boldest transgressors - the male Theseus, who sexually conquers the Amazonian queen Hippolyta, and the female Titania, who commits (drug-induced) bestiality with Bottom when he is an ass - and then couple their names together - not such a stretch, considering that Oberon accuses Titania of having an affair with Theseus. The resulting androgynous hybrid "Theotania" would resemble Theodora in both 
name and spirit. She is, in the coy gender-bending description from Feste's song, a lover "That can sing both high and low" (II.iii.40).

Faeries rule the Dionysian woods beyond the pale of the Apollonian court in A Midsummer Night's Dream. In the play's first scene in the woods, the lead trickster Puck asks a fairy, "How now, spirit! Whither wander you?" The fairy answers, "Over hill, over dale" (II.i.2; emphasis added). Using MND like a proto-GPS, Jackson locates Hill House outside the town of Hillsdale. As Eleanor makes her way toward Hill House, she describes it like a journey into fairyland. She wonders, "Will I, she thought will I get out of my car and go between the ruined gates and then, once I am in the magic oleander square, find that I have wandered into a fairyland, protected poisonously from the eyes of people passing? Once I have stepped between the magic gateposts, will I find myself through the protective barrier, the spell broken?" (13; emphasis added) Jackson was a committed student of witchcraft, magic, and the occult. $^{3}$ Her knowledge of fairy literature and mythology was extensive and not confined to Shakespearean references. For instance, she was familiar with Rudyard Kipling's work and would have known his book, Puck of Pook's Hill, where Kipling appropriates Shakespeare's Puck and installs him as presiding figure in a collection of original faery tales. The Pook's Hill of Kipling taps into the fairy mythology, particularly strong in Ireland, which understands the small circular hills dotting the countryside as "fairy forts." Locals regard these hills as sacred dwelling places for fairies, and any human who dares to tamper with these hills risks the powerful curse of the fairies. Popular culture often depicts faeries as cute, benign, harmless figures. Jackson knew as well as Shakespeare, however, that there is a malevolent side to fairy mythology in general, and to Puck specifically. Marjorie Garber reminds us: "Puck, we should note, is not Shakespeare's invention. The word was used, without the capital $P$, as early as 1000 B.C.E to describe an evil, malicious, or mischievous spirit or demon, and in the time of Chaucer and of William Langland, 'the pouke' was associated with the biblical Devil" (223). Jackson's Hill House essentially functions as a modernized fairy fort. This house in a hill is populated by poukes who use the lures of paranormal diversions and the prospects for romantic entanglements ["journeys end in lovers meeting"] to ensnare and punish intruders. ${ }^{4}$

The architect, patriarch, and spectral overlord of Hill House is the late Hugh Crain. He built this home as a place to confine and control his wife and daughters eighty years prior to the action of the novel. Ever since, Hill House has functioned as a charnel house where free will and true love go to die. Hugh Crain is cut from the same patriarchal cloth as Egeus and Theseus in A Midsummer Night's Dream. The first scene of the play lays the ground rules whereby husbands control unruly wives, fathers control disobedient daughters, and male rulers control rebellious subjects. Theseus, the Duke of Athens, admits that he has used violence to coerce Hippolyta, Queen of the Amazons, into marrying him:

Hippolyta, I woo'd thee with my sword,

And won thy love doing thee injuries;

But I will wed thee in another key,

With pomp, with triumph, and with reveling. (I.i.16-19)

In the midst of this abduction/engagement, Egeus arrives with his daughter Hermia in tow, threatening her life if she does not renounce her love for Lysander and accept her father's choice of Demetrius as husband:

I beg the ancient privilege of Athens:

As she is mine, I may dispose of her;

Which shall be either to this gentleman,

Or to her death, according to our law

Immediately provided in that case. (I.i.41-45)

The same patriarchal ethos that rules the family governs the state. Although Duke Theseus applies a softer rhetorical touch, his enforcement of the law is unequivocal:

What say you, Hermia? Be advis'd, fair maid. 
To you your father should be as a god:

One that compos'd your beauties, yea, and one

To whom you are but as a form in wax

By him imprinted, and within his power

To leave the figure, or disfigure it. (I.i.46-51)

Theseus does add one additional option short of death - lifelong celibacy as a cloistered nun: "Either to die the death or to abjure/For ever the society of men" (I.i.65-66). From the start, men assert an absolute and ruthless power over the bodies, agencies, and destinies of women in A Midsummer Night's Dream.

Three centuries later, Hugh Crain perpetuates this misogynistic legacy, exercising his paternal prerogatives to command total submission and obedience from his daughters, in life and after death. He composes a creepy manuscript of moral instruction, laying down the law for his daughters' strict religious and filial duties. The last chapter of this manuscript is eeriest of all because it is penned in Crain's own blood: "Daughter: sacred pacts are signed in blood, and I have here taken from my own wrist the vital fluid with which I bind you. Live virtuously, be meek, have faith in thy Redeemer, and in me, thy father, and I swear to thee that we will be joined together hereafter in unending bliss"' (125-26). Crain presumably produced two copies of this treatise, one for each of his daughters. The sole surviving copy discovered by Luke must have belonged to the elder daughter, since she was the last of the Crains to live in Hill House. The title page of her copy reads, "MEMORIES, for SOPHIA ANNE LESTER CRAIN; A Legacy for Her Education and Enlightenment During Her Lifetime From Her Affectionate and Devoted Father, HUGH DESMOND LESTER CRAIN; Twenty-first June, 1881" (123; emphasis in original). Make note of that date - the twenty-first of June. This manuscript could just as easily have been written by Egeus for Hermia. Both fathers uphold the same patriarchal expectations and prohibitions for their daughters, and both issue their decrees for rigid order against a backdrop of permissive anarchy on Midsummer's Eve.

Hermia explicitly defies Egeus, and Sophia implicitly defies Hugh Crain; but neither rebellion achieves a satisfactory resolution. Hermia does end up with the man she claims to love, Lysander, just as Helena ends up with the man she claims to love, Demetrius. But the young women's friendship is a casualty of the matchmaking process, and their marriages result in literally silencing them both. After leaving the forest, neither Helena nor Hermia ever speak again in the play. As Shirley Nelson Garner observes, "Recognizing that it is difficult for an actor to be on stage without any lines, as Helena and Hermia are for almost all of Act V, Shakespeare was undoubtedly aware that he was creating a portentous silence. Since Helena and Hermia are evidently married between Acts IV and V, their silence suggests that in their new roles as wives they will be obedient, allowing their husbands dominance" (138). Hermia may gain Lysander, but only at the price of losing her voice and severing her bond with Helena. The final tally is a victory for patriarchy and a defeat for women's autonomy and same-sex alliances.

Unlike Hermia and Helena, and unlike her younger sister, Sophia Crain never weds. "It was said that the older sister was crossed in love,"” according to Dr. Montague, "'although that is said of almost any lady who prefers, for whatever reason, to live alone" (56). Not only does Sophia resist the heteronormative compulsion to marry a man and have children, but she also forms a same-sex bond with a live-in partner. Dr. Montague explains, "She eventually took a girl from the village to live with her, as a kind of companion"” (56). Although it is never spelled out, the clear implication is that the older sister and her companion are lesbian lovers. Dr. Montague's description of the older sister as "crossed in love" invites comparison with the doomed "star-crossed lovers" Romeo and Juliet. As Lysander proclaims in the first scene of A Midsummer Night's Dream, "The course of true love never did run smooth" (I.i.134). Sophia dies, leaving Hill House to her surviving companion and initiating a property feud with the younger sister. Hounded day and night by the sister and by the disapproving townspeople of Hillsdale, the lonely companion ultimately commits suicide by hanging herself in the Hill House library. The forces of patriarchy and compulsory heteronormativity prevail 
again over those who transgress, just as surely as if the ghost of Hugh Crain had strangled Sophia and her companion with his cold, dead hands.

There can be no doubt, however, that Shirley Jackson's sympathies lie with the star-crossed subversive lovers. At the time she wrote The Haunting of Hill House, Jackson was married with four children. By all outward appearances, she was the embodiment of "true womanhood" that Egeus and Hugh Crain expected from their daughters. In her writing, however, Jackson deconstructs the domestic position she occupies. She offers a transvaluation of traditional family values and gender norms of Fifties America. Rather than depicting the home as a woman's natural and proper sphere a welcoming, protective, nurturing space for the "angel of the house" - Jackson depicts Hill House as a danger zone where women are haunted, hunted, and consumed. Eleanor vividly describes being in Hill House like being "a small creature swallowed whole by a monster" (29). Furthermore, rather than serving as the proving ground for women's conformity to heteronormative expectations, Hill House serves at times as a queer playground for subversive sexual desires.

Years before she became a wife, mother, and professional writer, Shirley Jackson formed an intimate bond with a fellow University of Rochester undergraduate, a French exchange student named Jeanne Marie Bedel. The two were frequently "accused" of being lesbians, though her biographer Ruth Franklin finds no evidence that she and Bedel were actually lovers. In any case, this brief but intense relationship initiated Jackson's enduring curiosity about lesbians. In her unpublished "Notes for a Story on the Grotesque," Jackson recalls,

My friend was so strange that everyone, even the man I loved, thought we were lesbians and they used to talk about us, and I was afraid of them and I hated them. Then I wanted to write stories about lesbians and how people misunderstood them. And finally this man sent me away because I was a lesbian and my friend went away and I was alone. (qtd. Franklin 62; emphasis added)

Was Jackson deeply closeted and in denial about her own sexuality? Or was this truly a case of mistaken sexual identity, confusing a deep homosocial bond with a homosexual affair? ${ }^{5}$ Either way, Jackson was extraordinarily sensitive to the strict taboos against lesbians and the compulsion to deny, suppress, or sublimate queer desire in mid-century America. These dynamics propel the erotic undercurrent between Eleanor and Theodora flowing beneath the surface of The Haunting of Hill House.

Personal experience may have supplied the initial inspiration for Jackson, but Shakespeare again provides a useful literary model for the artistic expression of same-sex desire. The love-hate relationship of Helena and Hermia in A Midsummer Night's Dream anticipates that of Eleanor and Theodora. After Puck misapplies the aphrodisiac "love-in-idleness" to Demetrius and Lysander, the two men who had vied for Hermia's affection abruptly redirect their ardor toward Helena. Helena believes she is the victim of a cruel prank. While she might expect mockery from the callous men, she is deeply wounded that her best friend would turn against her: "Lo, she is one of this confederacy!/Now I perceive they have conjoin'd all three/To fashion this false sport in spite of me" (III.ii.192-94). Helena and Hermia's argument escalates into a comic "catfight," but the emotional stakes are serious. Earlier Theseus scolded Hermia that her duties to her father "should be as a god" (I.i.47), meaning that she should subordinate herself to his superior (male) power. However, Helena offers an alternative paradigm of divine equality in describing her intimate friendship with Hermia:

We, Hermia, like two artificial gods,

Have with our needles created both one flower,

Both on one sampler, sitting on one cushion,

Both warbling of one song, both in one key,

As if our hands, our sides, voices and minds,

Had been incorporate. So we grew together,

Like to a double cherry, seeming parted,

But yet an union in partition,

Two lovely berries molded on one stem;

So, with two seeming bodies, but one heart. (III.ii.203-12) 
This striking passage weds celestial and nature imagery to offer an ideal model of love that is mutually chosen and freely given - a union of consenting equals in sharp contrast to the heartless bartering of Hermia's arranged marriage brokered by Egeus. Helena and Hermia were the truest of friends ... with benefits? Shakespeare's cherry metaphor may invite sexual connotations from contemporary audiences, though the OED only traces the cherry's association with virginity as far back as the nineteenth century ("Cherry, n5c"). However, in "Use Me but as Your Spaniel': Feminism, Queer Theory, and Early Modern Sexualities," Melissa E. Sanchez notes that the word "sides" was a synonym for "loins," implying that the intimacy between Helena and Hermia may have extended beyond platonic friendship (503). Helena and Hermia are idealized as two "sides" of one cherry, one heart, one sex - two halves of a single self.

Such an intimate union provides sustenance so long as the bond remains unbroken. When the two halves are ripped apart, however, the results are devastating and lethal. Jackson replicates Shakespeare's double-cherry/doppelganger dynamic through Eleanor's perceived relationship with Theodora. Tricia Lootens conducted archival research into the early drafts of The Haunting of Hill House, and she discovered a very revealing note from Jackson on one of the typescripts. "Theo against Nell, of course: to each of us - if we are fortunate - is given one other person, the true doppelganger, the other half of the self, and the union here is sometimes star-crossed, sometimes illicit, always deadly; it is the moment of perception when the victim sees his murderer, the brother discovers his sister, beauty destroys [embraces] the beast" (qtd. Lootens 163). Starting from her relationship with Jean Marie Bedel and embroidering it with Shakespeare's "star-crossed" unions from tragedy (Romeo and Juliet) and romantic comedy (Helena and Hermia), Jackson creates the blueprint for lesbian gothic in the relationship of Eleanor and Theodora.

Eleanor harbors romantic faith that "journeys end in lovers meeting." She has never been in love before, so she takes her cues from romances and fairy tales. As she winds her way to Hill House, she imagines herself on a fantastic voyage leading to an enchanted palace. In Eleanor's fantasy, she breaks an evil spell and frees the palace's inhabitants to "live happily ever after" (13). She envisions her reward as the love of a valiant hero: "Then, coming down from the hills there will be a prince riding, bright in green and silver with a hundred bowmen riding behind him, pennants stirring, horses tossing, jewels flashing" (14). The fairy tales all teach Eleanor that her happily-ever-after hero will be a man. However, the men who await her at Hill House are far from heroic: the avuncular, ineffectual Dr. Montague and the conceited rogue Luke Sanderson. By far the most attractive object of desire at Hill House is the eccentric artist Theodora.

Theodora signs her sketches with the masculine moniker "Theo," and she uses no surname, signifying that she is not marked by or beholden to any man. Eleanor's somber mood immediately brightens when Theodora arrives. The two become suitemates, with an adjoining bathroom connecting their bedchambers; Theo is in the "green room," which is the same color associated with Nell's imaginary prince. It is clear from the start that Eleanor is smitten. "Theodora came through the bathroom door into Eleanor's room; she is lovely, Eleanor thought, turning to look; I wish I were lovely. Theodora was wearing a vivid yellow shirt, and Eleanor laughed and said, 'You bring more light into this room than the window"' (33-34). Nell may not hear the echo of Romeo in that observation, but one bets that Jackson does: "But soft, what light through yonder window breaks?/It is the east, and [Theodora] is the sun" (II.ii.2-3).

Eleanor is increasingly drawn to Theodora, but she represses and deflects knowledge of her forbidden desire. Jackson devises a perfect case study of queer sublimation in the nail-painting scene. On their first full day at Hill House, Eleanor spends a luxurious afternoon in Theodora's bedroom, observing Theo at her beauty regimen. As she paints her nails, Theo idly observes, "I love decorating myself,' Theodora said, regarding her hand affectionately. 'I'd like to paint myself all over"' (85). She then offers to paint Eleanor's toenails red. Nell drowsily submits but is startled awake when Theo tells her she has dirty feet: 
Shocked, Eleanor sat up and looked; her feet were dirty, and her nails were painted bright red. "It's horrible," she said to Theodora, "it's wicked," wanting to cry. Then, helplessly, she began to laugh at the look on Theodora's face. "I'll go and wash my feet," she said.

"Golly." Theodora sat on the floor beside the bed, staring. "Look," she said. "My feet are dirty, too, baby, honest. Look."

"Anyway," Eleanor said, "I hate having things done to me." [...]

Eleanor looked at her feet again. "It's wicked," she said inadequately. "I mean - on $m y$ feet. It makes me feel like I look like a fool."

"You've got foolishness and wickedness somehow mixed up" (86; emphasis in original).

Freud would have had a field day with this nail-painting (Nell-painting) scene. The drowsiness with which Jackson introduces it invites interpretation like a (midsummer afternoon's) dream. Theodora's intimate act of painting Eleanor's toenails cherry-red is a tactile substitution for an even more intimate act Eleanor half-realizes she wishes Theodora were performing on her instead. Nell's lapsed defenses suddenly leap to attention, reminding her that she should be shocked, embarrassed, and disgusted by this dirty deed. Nell clearly enjoys being pampered and caressed by Theo, but she knows this is taboo: "It's horrible"; "it's wicked"; "I hate having things done to me." To quote Gertrude from Hamlet, "The lady doth protest too much, methinks" (III.ii.224).

The sexual fantasies kept at bay in the nail-painting scene come out to play later that night when the group experiences Hill House's first haunting. Eleanor is awoken by loud knocking sounds, which she immediately associates with her invalid mother trying to get her attention: "Coming, mother, coming,' Eleanor said, fumbling for the light. 'It's all right I'm coming.' Eleanor, she heard, Eleanor. 'Coming, coming,' she shouted irritably, 'just a minute, I'm coming'” (93; emphasis in original). That sure is a lot of coming! It turns out Theodora is the person calling out Eleanor's name and soliciting this response. The OED defines "coming" (now more popularly "cumming") in the sexual sense ("to experience sexual orgasm") as dating back to Renaissance drama, citing the first known example from Dekker and Middleton's Honest Whore ("come, v22"). Recall that Feste's love song uses the term, too: "O stay and hear, your true love's coming" (II.iii.40; emphasis added). By 1959, no writer could have a character announce she is "coming" six times in the span of four sentences and be ignorant of the orgasmic associations this would inevitably elicit from readers. We are not privy to Eleanor's dreams before being roused by the spirits of Hill House, but it is safe to guess that her afternoon delight with Theo factored into her nocturnal fantasies. One might expect that the imperious ghost of Hugh Crain is angry at the indecency committed under his roof and is chastising naughty Nell and Theo. But if anything the haunting has the opposite effect, what with all the coming, knocking, and banging.

Far from punishment, the first haunting feels like a consummation, an elaborate manifestation of Eleanor's suppressed desire bursting out, rattling the whole house and nearly blowing down the door. "Little Nell, Little Nell, let me in!" The pulsating rhythm of the first haunting mimics sex: "It pounded regularly for a minute, and then suddenly more softly, and then again in a quick flurry, seeming to be going methodically from door to door at the end of the hall" (94). Tellingly, the experience ends with the arrival of Dr. Montague and Luke. This is not because the men save the women from a terrifying experience, but because the men interrupt a women-only experience which does not include them, one which left the suitemates shivering in fear and excitement in each other's arms. Dr. Montague notes that he and Luke were diverted away by the spirits, leading him to ask "doesn't it seem that the intention is, somehow, to separate us?"” (99) He misses the point. The intention is to get rid of the men so that the women can be alone. As the group reconvenes for a nightcap, Eleanor's dizzy thoughts sound distinctly post-coital: "They spoke lightly, quickly, and gave one another fast, hidden, little curious glances, each of them wondering what secret terror had been tapped in the others, what changes might show in face or gesture, what unguarded weakness might have opened the way to ruin" (98). Nell is frightened by her initiation and fears it may lead to ruin - but she is also giddy in the afterglow of ecstasy. Journeys end in lovers meeting.

Hill House sends mixed signals about its agenda. Is the house a space for punishing queer desires or for indulging and hosting them? The first night's haunting simulates Nell's sexual fantasies and brings 
her closer to Theo. In this respect, Hill House functions as a matchmaker like Puck liberally dispensing love potion. However, the events that take place the following day problematize this reading, as Hill House functions more like a devilish pouke, sowing seeds of dissent and driving a wedge between Nell and Theo. The troubles begin when Luke discovers a message written in chalk on a hallway wall: "HELP ELEANOR COME HOME" (107). Eleanor is understandably terrified at being targeted by the house. Her fear quickly morphs into paranoia, however, as she accuses first Theo and then Luke of writing the message on the wall to humiliate and bully her. As with Helena and Hermia's falling out in the forest, love transforms abruptly into hate once Eleanor believes that Theodora is head of a confederacy to destroy her.

Much as Hill House mimicked Eleanor's sexual fantasies the night before, it now enacts her lust for revenge. Jackson creates an inverse companion piece for the erotic nail-painting scene with the sadistic "bloody chamber" scene. Feuding Nell and Theo each retire to their separate bedrooms, but Theo soon yelps in outrage. Nell enters to discover the green room and its contents splashed in red: "It looks like paint,' she said hesitantly. 'Except' - realizing - 'except the smell is awful." Theo corrects her: “It's blood"' (113). Of course, Nell never had the time, opportunity, or resources to vandalize Theo's room in person. Nevertheless, the clairvoyant Theo senses that the telekinetic Nell caused this to happen. She may be right. Nell's subsequent behavior is certainly suspicious. Rather than being shocked or worried, she is unusually calm and cold, blaming the victim for her own victimization. Because of the vandalism, all of Theo's clothes are sullied, leading Nell to admonish her and insist that she be cleaned. Their exchange begs comparison to the nail-polish scene, when scarlet-toed Nell was the one who felt dirty. Now the polish is on the other foot, so to speak. Nell reinforces this link as she silently seethes, "She is wicked, Eleanor thought, beastly and soiled and dirty" (116).

The bloody chamber scene also bears the signature of Hugh Crain. "All of them stood in silence for a moment and looked at HELP ELEANOR COME HOME ELEANOR written in shaky red letters on the wall paper over Theodora's bed" (114). Writing misogynist messages in blood is Crain's calling card. In Nell's sexual fantasies, Theo was poised to "help Eleanor come" the night before. Now the patriarchal spirit of Hugh Crain tries to seize the day, intervening to "help Eleanor come home." This entreaty could be his pitch to recruit her as a permanent resident at Hill House, cloistering her from temptation and mortal sin. Or the message could refer to Eleanor's heavenly home, echoing Crain's instructions to his daughters to obey his and God's commandments so that they could all "'be joined together hereafter in unending bliss”' (126). According to Crain's patriarchal ideology, Nell experienced the wrong kind of bliss the night before. The message, scrawled tellingly above Theo's seductive bed, attempts to dissuade Nell from sexual dalliance and sequester her back in the home where Crain thinks she belongs.

It is also important to recognize how Eleanor has internalized a sense of misogynist self-revulsion. More than the words, the medium is the message: blood. Tricia Lootens observes of the bloody chamber scene: "The menstrual imagery seems unmistakable here: Hill House echoes and amplifies Eleanor's hatred of 'dirty' female bodies, including her own. Theodora's bright clothes are trampled and soaked in blood. Even more significantly, she herself is bloodied - literally rendered a scarlet woman - and Eleanor's name, like Hugh Crain's in the obscene book of 'moral' instruction, is written on the walls in blood" (164). The manifest content is vivid and strange: a blood-splashed bedroom, tarnished clothes, and a cryptic message in scarlet letters that reads more like a parent's command than a lover's invitation. The latent content is millennia old and sadly familiar: sexual shaming, demonization of women's bodies as innately sinful and dirty, and ruthless prohibitions against queer desire and deviant sexuality.

Jackson's bloody chamber scene draws inspiration again from Shakespeare, but this time from tragedy. Plenty of Shakespearean tragedies are soaked in blood; but no play combines sex and violence, moralistic opprobrium, misogynistic revulsion at women's inherently corrupt bodies, and a dueling rivalry played out in a bloody bedchamber better than Othello. Whereas classic comedies conclude with marriage, this tragedy instead begins with a secret wedding between Othello and Desdemona and it all goes downhill from there. Here, too, the medium is the message: blood. When Brabantio 
learns that his daughter has eloped with a Moor, he exclaims, "O treason of the blood!" (I.i.167). The treason has only begun. Vengeful Iago drives Othello mad with jealousy, convincing him that his new bride is cheating on him with Cassio. As proof of her infidelity, Iago claims to have seen Cassio with Desdemona's handkerchief, her first love token from Othello. Confronted with this pseudo-evidence, Othello becomes apoplectic with rage: "O blood, blood, blood!" (III.iii.454). Even before he has consummated his marriage, he already plots to kill his wife. The scene of the crime is emblematic of Desdemona's alleged sin: "Thy bed, lust-stained, shall with lust's blood be spotted" (V.i.36). Once Othello arrives at her bedchamber, however, he changes his mind - not about killing her, but about staining her bed with blood:

\author{
It is the cause, it is the cause, my soul! \\ Let me not name it to you, you chaste stars, \\ It is the cause. Yet I'll not shed her blood, \\ Nor scar that whiter skin of hers than snow \\ And smooth as monumental alabaster: \\ Yet she must die, else she'll betray more men. (V.ii.1-6)
}

The stars are not the only chaste ones in this scene. Desdemona is innocent of the charge. A plea of "not guilty" is inadmissible, however, when it comes to the unpardonable crime of being a woman. Othello condemns and executes his virginal wife on her spotless wedding sheets - all on the strength of one unreliable witness, Iago, and one bogus piece of evidence, the handkerchief. As Marjorie Garber argues, "The white handkerchief marked with red becomes - because Othello makes it so - another version of the white wedding sheets that are so often mentioned in the play. The red embroidery becomes the emblem of the blood of her virginity, and Othello is now convinced that Cassio has had them both" (611). The truth is ultimately revealed, as Othello discovers too late that Iago duped him. He responds by stabbing himself, leading Lodovico to cry out, "Oh, bloody period!" (V.ii.367). The conclusion is often staged with Othello collapsing on the bed to join his dead wife - turning the white sheets red with violence and shame. The ideological and psychosexual palette is all there, in bright globs of primal red, for Jackson to paint her bloody chamber in tragic Shakespearean colors.

Othello is a direct descendent of English morality plays, where allegorical figures of Virtue and Vice contend for the soul of an Everyman protagonist. In the terminology of that tradition, Iago represents Vice and Desdemona represents Virtue. Shakespeare complicates his dramatic inheritance, however. The traditional morality play instructs the laity in how to resist the temptations of Vice and follow the example of Virtue in order to earn salvation in the end. Vice wins out in Othello, however, leaving the protagonist dead and damned. Shakespeare adds a further level of complexity by internalizing the battle between Virtue and Vice, a process called psychomachia. Iago and Desdemona are rich and nuanced characters, not allegorical abstractions; but Othello's ultimate struggle is not with either of these characters - it is with himself. Will he listen to his innermost doubts and fears, or will he follow his better judgment and trust his love? The conclusion provides a tragic answer, not because Iago outmaneuvered Desdemona, but because Othello allowed his worst impulses to get the better of him. ${ }^{6}$

Jackson stages a similar battle, but like Shakespeare before her, she complicates her inheritance, repurposing Othello and the morality play tradition to serve starkly different ends. For one, she reverses Shakespeare's psychomachia. In The Haunting of Hill House, Eleanor's internal struggle to use the taxonomy of the era, her id's desire for Theo versus her superego's prohibition against such desire - is projected outward and manifests externally in Hill House. Jackson appropriates morality play tropes while upending their doctrinaire agenda. By the standards of the morality play, or for that matter by the standards of Fifties America, Hugh Crain's moral code would have been associated with Virtue, with heteronormative family values. On the other hand, Theo's aberrant lesbianism would have been associated with Vice, and thus piously denounced. Jackson's sympathies lie instead with Nell and Theo, depicting their opponent Hugh Crain as the novel's arch-villain. Thoroughly disgusted by Crain's moral instruction manual, Theo declares, "'Hugh Crain, [...] you were a dirty old man, and 
you made a dirty old house and if you can still hear me from anywhere I would like to tell you to your face that I genuinely hope you will spend eternity in that foul horrible picture and never stop burning for a minute" (126). Theo is usually cool-headed and prefers to quip with droll sarcasm. The moral instruction manual piques her fury, however, doubtlessly because she knows what it is like as a lesbian to be castigated as unnatural and damned by the Hugh Crains of the world.

Eleanor is roused by Theodora's defiant bravado. If it must come down to a choice, Nell chooses Theo over Crain. As the two walk silently on the lawn outside Hill House, Eleanor finally admits to herself that she loves Theodora. "Nothing irrevocable had yet been spoken, but there was only the barest margin of safety left them; each of them moving delicately along the outskirts of an open question, and, once spoken, such a question - as 'Do you love me?' - could never be answered or forgotten. [...] Each knew, almost within a breath, what the other was thinking and wanting to say; each of them almost wept for the other" (128-29). Eleanor remains incapable of asking "Do you love me?" let alone saying "I love you." Nell is, to use the terminology of the gay rights movement a generation later, deeply closeted. She desires Theo, but she dares not call her taboo love by its true name.

Eleanor does not need to speak, however, to be heard by Hill House. Having already hacked her mind, the house knows the tide is turning in Theo's favor. The hauntings increase in frequency and intensity as the patriarchal forces of Hill House mount a vigorous defense against the insurgent queer desire that threatens Hugh Crain's hegemony. Eleanor is driven to the brink of madness and disintegration. Overwhelmed by the onslaught, she reaches her breaking point: "It is too much, she thought. I will relinquish my possession of this self of mine, abdicate, give over willingly what I never wanted at all; whatever it wants from me it can have" (150). Abandoning all resistance, she speaks the magic words: “'I'll come,' she said aloud, and was speaking up to Theodora, who leaned over her" (150; emphasis added). The haunting suddenly subsides, apparently because the patriarchal forces have triumphed. "HELP ELEANOR COME HOME," Hugh Crain had scrawled in blood; now he receives Eleanor's surrender: "I'll come."

Readers should recall, however, that the loaded term coming also has distinct connotations with Nell's desire for Theo. Jackson conspicuously stages the "surrender" scene in such a way that Eleanor delivers the pivotal line, "I'll come," while gazing up at Theodora. Is Nell vowing to come home to Hill House? Or is she vowing to come for Theo? In a decisive encounter the next morning, Nell makes her allegiances clear. She announces her decision to join Theo after they leave Hill House: "I'm coming with you"” (153; emphasis added). Theo is confused, so Nell explains, "'Back with you, back home. I' and Eleanor smiled wryly - 'am going to follow you home"” (153). Resorting again to that loaded eroticized language, Nell pleads, “I'll come, you know,' Eleanor said. 'I'll just come” (154). Nell pathetically begs to be taken home, but she is cruelly spurned by Theo. Jackson is surely drawing here upon a similarly cringe-worthy scene in A Midsummer Night's Dream, where Nell's namesake Helena prostrates herself before Demetrius and masochistically begs him to treat her as his dog:

DEMETRIUS: Do I entice you? Do I speak you fair?

Or rather do I not in plainest truth

Tell you I do not, nor I cannot love you?

HELENA: And even for that do I love you the more.

I am your spaniel; and, Demetrius,

The more you beat me, I will fawn on you.

Use me but as your spaniel, spurn me, strike me,

Neglect me, lose me; only give me leave,

Unworthy as I am, to follow you.

What worser place can I beg in your love -

And yet a place of high respect with me -

Than to be used as you use your dog? (II.i.199-210)

So humiliating, yet so familiar. Theo likewise compares Nell to an unwanted animal - "I am not in the habit of taking home stray cats"' - but rather than defend herself against this insult, Nell demurs, 
“I $a m$ a kind of stray cat, aren't I?"” (154; emphasis in original). Echoing heartless Demetrius, Theo asks, “Do you always go where you're not wanted?"” Nell meekly replies, “I've never been wanted anywhere" (154; emphasis in original).

As far as Nell's future with Theo goes, there will be no home/coming. There will also be no "coming out." The OED traces the term "coming out" only back as far as 1970 in the sense of "to acknowledge or declare openly that one is homosexual" ("come, v13a"). Nevertheless, the symbolism of that act crossing outside of one's former identity, "coming out of the closet" in which one used to hide - is consistent with what Nell tries to do privately when she tells Theo "I'll come." Rather than encouraging Nell to come out, Theo rejects her. It is as if Theo channels her inner Theseus and essentially condemns Nell to abjure the society of her own. Put more bluntly, Nell tries to come out of the closet but Theo effectively shoves her back in. Once again, Jackson displays the insidiousness of internalized ideology, as the ultimate agent enforcing censure against Nell's queer desire turns out to be the lesbian Theo instead of the patriarch Hugh Crain.

Having nowhere else to turn, Nell resigns herself to the cloister of Hill House. In desperation, she attempts to follow in the footsteps of Sophia Crain's companion by killing herself in the library. When that effort fails, she fatally crashes her car into a tree in the driveway exiting Hill House. The house had briefly functioned like the woods in A Midsummer Night's Dream, a playground for queer desire. However, it ultimately reverts to a hospice where subversive sexuality is isolated, quarantined, and euthanized. The novel's conclusion implies that Nell's undead spirit continues to reside in the haunted house, but she achieves no sense of belonging, tenderness, sorority, or resolution there. Hill House becomes Nell's hermetically sealed Closet.

Eleanor entered Hill House enchanted by dreams of adventure and fantasies of love. Jackson maps a path for Eleanor through Hill House guided by Shakespeare's romantic comedies and tragedies. Nell fervently yearns to realize the ideals promised in Feste's love song:

O mistress mine, where are you roaming?
O stay and hear, your true love's coming,
That can sing both high and low.
Trip no further, pretty sweeting;
Journeys end in lovers meeting,
Every wise man's son doth know. (II.iii.38-43)

Perhaps "Every wise man's son" has the advantage to achieve this ideal, but daughters have a tougher time. The laws of love are written by and for heterosexual men, and their heteronormative ideology is indoctrinated and perpetuated across the gender spectrum. According to Puck, the sexual order eventually sorts itself out: "Jack shall have Jill,/Nought shall go ill" (III.ii.461-62). But what happens when one Jill desires another Jill? This is the question posed by Shirley Jackson in The Haunting of Hill House. The answer is not the stuff Dreams are made on, so much as nightmares and horror stories. Eleanor pursues the ideals of Feste's love song, but she ends up more like the doleful and abandoned figure of his death song:

Come away, come away death,

And in sad cypress let me be laid.

Fie away, fie away breath,

I am slain by a fair cruel maid.

My shroud of white, stuck all with yew,

O prepare it.

My part of death no one so true

Did share it. (II.iv.51-58)

For Eleanor, journeys do not end in lovers meeting. Nor do journeys end simply and definitively in lovers dying. In effect, her journey never ends at all. Shakespeare's A Midsummer Night's Dream concludes with a release. Puck mends all rips to the social fabric by reassuring the audience that the preceding action has all been a diverting dream: 
If we shadows have offended,

Think but this, and all is mended,

That you have but slumber'd here

While these visions did appear.

And this weak and idle theme,

No more yielding but a dream,

Gentles, do not reprehend:

If you pardon, we will mend. (V.i. 410-16)

Shirley Jackson offers no such pardons or paroles. Eleanor remains perpetually suspended in time and space, arrested by hostile forces, held captive in the wrong genre, and condemned to solitary confinement. She may tap her red toenails all she likes, but she is doomed to discover there's no place like home at Hill House - and no exit from this midsummer's nightmare. The novel concludes as it begins, inscribing a circular prison with no escape. Nell remains forever trapped in a cycle of unreciprocated desire, homeless exile, and unending loneliness - never coming and never going "and whatever walked there, walked alone" (182).

\section{Notes}

1. See Colin Haines, "Frightened by a Word": Shirley Jackson and Lesbian Gothic (Uppsala Universitet, 2007).

2. For another excellent example of an artwork that uses the traditions of "midsummer madness" for the purposes of horror, see the film Midsommar (2019) directed by Ari Aster.

3. According to biographer Ruth Franklin, Jackson's interest in witchcraft began as an undergraduate at the University of Rochester and persisted throughout her life. "Witchcraft, whether she practiced it or simply studied it, was important to Jackson for what it symbolized: female strength and potency. The witchcraft chronicles she treasured $[\ldots]$ are stories of powerful women: women who defy social norms, women who get what they desire, women who can channel the power of the devil himself" (Franklin 261).

4. Late in the novel, Eleanor seems demonically possessed as she runs down the hallways and bangs on the doors, replicating the earlier scare tactics of Hill House. Identifying herself as one of the puckish spirits haunting the house, she muses, "what fools they are, she thought, we trick them so easily" (170). This clearly paraphrases Puck's oft-quoted line from A Midsummer Night's Dream: "Lord, what fools these mortals be!" (III.ii.115).

5. There were limits to Jackson's progressivism on the subject of lesbianism. According to Ruth Franklin, Jackson was disturbed to find her novel Hangsaman described as "an eerie novel about lesbians" in Jeannette Foster's 1956 book Sex Variant Women in Literature. "Jackson was vehemently opposed to the idea that her fiction might have a lesbian subtext - perhaps too vehemently opposed, considering how often figures who may be understood as lesbian appear in her fiction" (Franklin 440). While Jackson resisted and feared having her fiction labeled as lesbian, she also conceded that perhaps her characters' deeper motives were opaque even to their author. Franklin posits, "The fear Jackson refers to is not fear of lesbianism - or, at least, not only fear of lesbianism. It is the fear of what lesbianism represented to her, something that on one level she fervently desired even as she feared it: a life undefined by marriage, on her own terms" (442).

6. Iago offers a number of reasons for his plot to destroy Othello and Desdemona. Among his unnamed motives, however, may be sexual jealousy. Iago may seek to displace Desdemona because he desires Othello for himself. One of the earliest queer readings of Othello was offered in "Iago Psychoanalytically Motivated" by Stanley Edgar Hyman - the husband of Shirley Jackson.

\section{Disclosure Statement}

No potential conflict of interest was reported by the author.

\section{Notes on contributor}

Graley Herren is a Professor of English at Xavier University in Cincinnati. He is the author of books on Samuel Beckett and Don DeLillo, he edited five volumes of the Text $\triangleleft$ Presentation book series, and he serves on the executive board for the Comparative Drama Conference. 


\section{Works Cited}

Franklin, Ruth. Shirley Jackson: A Rather Haunted Life. W. W. Norton, 2016.

Garber, Marjorie. Shakespeare After All. Pantheon, 2004.

Garner, Shirley Nelson. "A Midsummer Night's Dream”: 'Jack Shall Have Jill/Nought Shall Go Ill.” 1981. Rpt.” A Midsummer Night's Dream: Critical Essays, edited by Dorothea Kehler, Garland, 1998, pp. 127-43.

Haines, Colin. "Frightened by a Word": Shirley Jackson and Lesbian Gothic. Uppsala Universitet, 2007.

Hyman, Stanley Edgar. "Iago Psychoanalytically Motivated." The Centennial Review, vol. 14, no. 4, 1970, pp. 369-84. Jackson, Shirley. The Haunting of Hill House. Penguin, 1959.

King, Stephen. Danse Macabre. Everest House, 1981.

Lootens, Tricia. "'Whose Hand Was I Holding?': Familial and Sexual Politics in Shirley Jackson's the Haunting of Hill House.” 1991. Rpt." Shirley Jackson: Essays on the Literary Legacy, edited by Bernice M. Murphy, McFarland, 2005, pp. 150-68.

Oxford English Dictionary. Web. OED Online, Mar. 2020. Accessed 27 Mar. 2020.

Sanchez, Melissa E. Shakespeare and Queer Theory. The Arden Shakespeare. Bloomsbury, 2019.

- - " “Use Me but as Your Spaniel': Feminism, Queer Theory, and Early Modern Sexualities." PMLA, vol. 127, no. 3, 2007, pp. 493-511. doi:10.1632/pmla.2012.127.3.493.

Shakespeare, William. Hamlet. The Second Quarto, 1604-05. Arden Shakespeare Third Series. Eds. Ann Thompson and Neil Taylor. Bloomsbury, 2006.

-_- A Midsummer Night's Dream. Arden Shakespeare Second Series. Ed. Harold Brooks. Bloomsbury, 1979.

-_- Othello. Arden Shakespeare Third Series. Ed. E. A. J. Honigmann. Bloomsbury, 1996.

-_- Romeo and Juliet. Arden Shakespeare Third Series. Ed. René Weis. Bloomsbury, 2012.

-_- Twelfth Night. Arden Shakespeare Third Series. Ed. Keir Elam. Bloomsbury, 2008. 